\title{
INVENTARISASI KEANEKARAGAMAN ANGGREK (Orchidaceae) DI HUTAN RESORT WAY KANAN BALAI AMAN NASIONAL WAY KAMBAS SEBAGAI SUMBER INFORMASI DALAM MELESTARIKAN PLASMA NUTFAH
}

\author{
Dwi Agustin \\ Hening Widowati
}

\begin{abstract}
Pendidikan Biologi FKIP Universitas Muhammadiyah Metro
E-mail: dwie_agustin@rocketmail.com,adwi57811@gmail.com
\end{abstract}

\begin{abstract}
Orchid is one of the plants that have different characteristics in each species and its habitat. Orchids (Orchidaceae) or nation is a group that is protected by Government Regulations Number. 7 Th.1999. It is necessary to look at the type of data collections and save it, and look at the characteristics of tropical forests in the Resort Way Kanan. This research aims to inventory orchid the found in Forest Resort of Way Kanan. This research was conducted in December 2014 until January 2015, using purposive sampling method and using techniques Line transeck, cut the line following the path of the Post traking Right Way to the SRS (Sumatran Rhino Sanctuary), in this research using 4 stations between stations within $2 \mathrm{~km}$. The results of this study were obtained 23 species of orchids with 9 genera and 14 species include: the genus Dendrobium, Dendrobium creatceum, Dendrobium crumenatum, genus Grammatophyllum, Grammatophyllum scriptum BL, Agrostophyllum genus, the genus Cymbidium, Cymbidium chloranthum, Cymbidium hartinahianum, Calanthe genus, the genus Bulbophyllum, Arachnis sp, Angraecum didieri, Ascocentrum miniatum, Ascocentrum aureum, Coelogyne foerstermanni, golden shower Oncidium, Phalaenopsis amabilis, Spathoglottis sp. Having analyzed the data obtained it has a value equal to $46 \%$ of species density and relative density of $88.36 \%$ with a diversity index value of 1.3, based on the criteria of the Shannon-Wienner in Fachrul abundant species diversity can be expressed with the criteria being. The results of this study compiled into resources in conserving germplasm in the form of books and banner summary information, because there are some orchids are found in Forest Resort Way Kanan Balai Way Kambas National Park in Government Regulations Number. 7 Th.1999 is a protected species of orchids. Orchid is a protected plant species, therefore it is necessary for us to maintain and preserve it.
\end{abstract}

Kata Kunci: inventarisasi, anggrek (Orchidaceae), Resort Way Kanan Balai Taman Nasional Way Kambas, sumber informasi.

Anggrek merupakan salah satu jenis tanaman hias yang memiliki bunga yang khas dengan mahkota yang indah dan warna yang menarik, hal ini membuat anggrek menjadi primadona di kalangan petani tanaman hias dan para pecinta tanaman hias seperti para pecinta bunga anggrek. Saat ini anggrek-anggrek hasil persilangan petani telah banyak ditemukan di kios- kios penjual tanaman hias dengan berbagai variasi warna dan jenis, tanpa diketahui jenis anggrek sebelum dilakukan persilangan (anggrek alam) yang merupakan plasma nutfah dalam persilangan anggrek hibrida oleh petani. Anggrek alam atau anggrek spesies merupakan anggrek yang belum mengalami persilangan yang masih hidup alami di habitat aslinya. Anggrek 
alam atau anggrek spesies hidup alami di habitat aslinya yakni hutan-hutan yang memiliki kelembaban, intensitas cahaya dan kondisi tanah yang sesuai dengan syarat tumbuh anggrek. Hutan Resort Way Kanan Balai Taman Nasional Way Kambas merupakan salah satu dari dua kawasan konservasi yang berbentuk Taman Nasional di Provinsi Lampung selain TNBBS (Taman Nasional Bukit Barian Selatan). Hutan Resort Way Kanan Balai Taman Nasional Way Kambas memiliki kekayaan flora dan fauna yang terjaga dengan baik. Anggrek alam atau anggrek spesies saat ini dalam kondisi yang hamper punah seperti pernyataan Sarwono (2002) yang menyatakan jika anggrek alam atau anggrek spesies mulai terancam punah karena rusaknya ekosistem hutan saat ini. Selain itu perlu diadakannya pendataan atau pencataan keanekaragaman jenis anggrek di Hutan Resort Way Kanan Balai Taman Nasional Way Kambas yang memiliki kekayaan flora dan faunanya. Kondisi anggrek yang hampir punah membuat perlu diadakannya pencatatan atau pendataan jenis anggrek di Hutan Resort Way Kanan yang hasil pencatatannya dijadikan sebagai sumber informasi pelestarian plasma nutfah dalam bentuk buku ringkasan dan baner informasi. Penelitian ini bertujuan untuk mengetahui keanekaragaman jenis anggrek di Hutan Resort Way Kanan, serta untuk mengetahui karakteristik anggrek dan karakteristik habitat anggrek di Hutan Resort Way Kanan dan untuk menyusun hasil penelitian berupa buku ringkasan dan baner informasi.

Penelitian ini bertujuan untuk mengetahui keanekaragaman anggrek di Hutan Resort Way Kanan Balai Taman Nasional Way kambas, untuk mengetahui karakteristik anggrek dan karakteristik habitat di Hutan Resrot Way Kanan, selain itu untuk menyusun sebagai sumber informasi dari hasil pendataan anggrek di Hutan Resort Way Kanan.

Inventarisasi merupakan salah satu dasar penting bagi penilaian keragaman hayati, dan dengan demikian pengembangan panduan lapangan pun menjadi prasayarat penting (Indrawan, 2007:458). Inventarisasi keanekaragaman anggrek (Orchidaceae) merupakan suatu pengumpulan data dan pencatatan dalam suatu tempat dimana terdapat tumbuhan anggrek di lingkungan tersebut dengan keberagaman jenis yang bervariasi. Inventarisasi juga dapat dilakukan untuk mendata dan mencatat berbagai jenis tumbuhan yang tersebar di daerah tertentu seperti hutan.

Anggrek spesies atau anggrek alam adalah anggrek yang dapat ditemukan di alam dan sama sekali belum disilangkan dengan tanaman anggrek lainnya, anggrek alam ini dapat ditemukan di kawasan hutan, topografi ataupun vegetasi-vegetasi lain. Meskipun masih berupa anggrek yang belum disilangkan anggrek alam masih memiliki bentuk dan warna yang indah serta menarik (Kartohadiprodjo, 2009). Anggrek alam memiliki bentuk dan variasi warna yang tak kalah menarik jika dibandingkan dengan anggrek hasil persilangan, bahkan anggrek alam dapat dijadikan tanaman induk untuk persilangan jenis anggrek berikutnya. Variasi dan warna-warna yang menarik ini yang menjadikan keunggulan dari tanaman anggrek jika dibandingkan dengan tanaman lainnya. Anggrek alam banyak ditemukan di hutan-hutan yang memiliki tingkat kelembaban tertentu, tergantung dengan jenis anggrek yang menempati habitat tertentu. Bunga anggrek 
tersusun majemuk dan mempunyai karakteristik yang khas yang membedakan dari anggota suku yang lain, seperti tangkai pada bunga anggrek yang berlekuk-lekuk mengikuti cahaya matahari, selain itu anggrek memiliki tiga sepal (kelopak bunga), satu di antaranya terletak di bagian belakang yang menghadap ke atas yang dinamakan sepal dorsal. Anggrek juga memiliki tiga petal (mahkota bunga) yang letaknya berselang-seling dengan kelopak bunga. Satu helai petal terletak di bawah berbentuk mirip dengan lidah sehingga disebut labellum (bibir bunga) (Indarto,2011:14).

Tempat atau lingkungan serta objek pun saat ini dapat dijadikan sebagai sumber belajar, dengan memperoleh informasi dari lingkungan dan objek sekitar tentu informasi yang diperoleh lebih segar (tidak usang) (Sanjaya, 2011). Tempat atau lingkungan adalah salah satu tempat yang dapat dijadikan sebagai sumber belajar, dengan mempelajari dan memperoleh informasi dari lingkungan dan objek sekitar.

\section{METODE}

Penelitian yang dilakukan yakni penelitian dengan pendekatan kualitatif dan bersifat deskriptif. Khadiran peneliti berperan dalam pengambilan data dan instrumen atau alat dalam pengambilan data tersebut. Data yang diperoleh adalah jenis data deskriptif kualitatif yang diperoleh dari lapangan atau tempat penelitian. Sumber data yang diperoleh dari beberapa kriteria yang dikumpulkan meliputi, nama anggrek baik Indonesia (nama daerah) atau pun Latin, jenis anggrek, habitat anggrek, tanaman inang (jika anggrek epifit), jumlah anggrek, serta keterangan dan manfaat anggrek.

Penelitian serta pengambilan sampel dilakukan kurang lebih 2 bulan dengan beberapa fase, mulai dari praobservasi, observasi, hingga penelitian dan pengambilan sampel. Teknik pengumpulan data ini dilakukan dengan menggunakan metode purposive sampling yang merupakan metode untuk menentukan wilayah pengambilan sampel yang didasarkan pada tujuan dan pertimbangan tertentu. Dan teknik yang digunakan dalam pengambilan sampel adalah teknik line transect (transek garis), jenis line transect yang digunakan adalah jenis transect berseling.

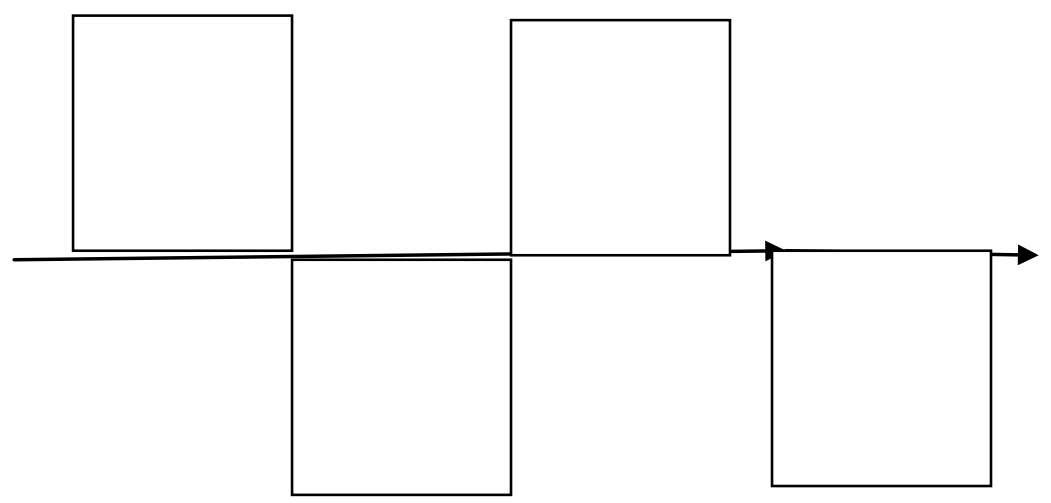

Gambar 1. Contoh Petak Line Transect Lengkap dengan Rancangan Stasiunnya Sumber: Kuswanda (2012:88) 
Setelah memperoleh data, maka data yang diperoleh diidentifikasi dengan mencari nama Indonesia, nama latin, Status Keanekaragamannya (dilindungi atau tidak), dan dianalisis dari jumlah tiap jenis yang ditemukan. Analisis dilakukan dengan menggunakan beberapa rumus menurut Fachrul (2007):

a. Kerapatan Relatif

$\% K R=\frac{\text { Kerapatan Suatu jenis }}{\text { kerpatan Seluruh jenis }} x 100 \%$

b. Indeks Keanekaragaman

$H^{\prime}=-\sum\left(\frac{n i}{N} \log \frac{n i}{N}\right)$

Keterangan:

$\mathrm{H}^{\prime}=$ Indeks $\quad$ Keanekaragaman

Shannon-Wienner

ni=jumlah individu dari suatu jenis

$\mathrm{N}=$ Jumlah total individu seluruh jenis. c. Rumus Kerapatan Spesies:

$$
\mathrm{Di}=D i=\frac{\sum \mathrm{Ni}}{\mathrm{A}}
$$

Keterangan:

$\mathrm{Di}=$ kerapatan spesies $\mathrm{i}$

$\mathrm{Ni}=$ jumlah total spesies $\mathrm{i}$

$\mathrm{A}=$ total luas area pengamatan $\left(\mathrm{m}^{2}\right)$

\section{HASIL}

Hasil yang diperoleh dari inventarisasi anggrek di Hutan Reort Way Kambas Balai Taman Nasional Way Kambas memperoleh 23 jenis anggrek pada semua stasiun yang berjarak 10Km. Pengambilan data anggrek di Hutan Resort Way Kanan ini dilakukan dengan mengambil data anggrek baik yang menempel pada pohon (epifit) dan teresterial (di tanah). Berikut adalah grafik (gambar) tentang jumlah keberadaan anggrek epifit dan tersterial yang ditemukan pada setiap stasiunnya

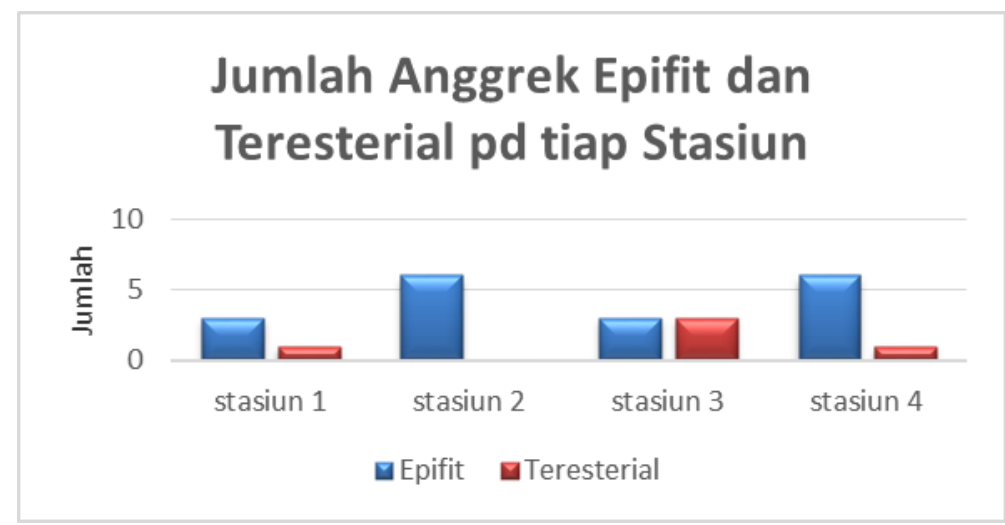

Gambar 2. Jumlah Anggrek Epifit dan Teresterial pada Tiap Stasiun 


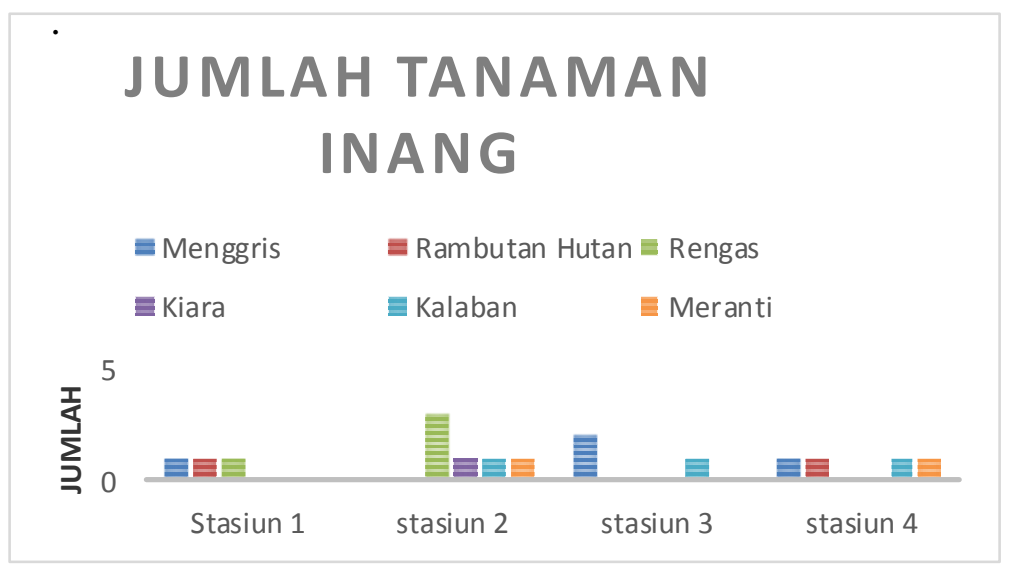

Gambar 3. Jumlah Tanaman Inang

Hasil yang diperoleh ternyata anggrek epifit lebih banyak ditemukan jika dibandingkan dengan anggrek teresterial. Tanaman yang dijadikan sebagai tempat menempel anggrek juga beragam, berikut adalah grafik (gambar) tanaman yang sering dijadikan sebagai tempat menempel anggrek

\section{PEMBAHASAN}

Hasil dari penelitian Inventarisasi Anggrek di Hutan Resort Way Kanan mendapatkan 23 jenis tanaman anggrek yang didapatkan dari 4 stasiun yang tiap stasiunnya berjarak $2 \mathrm{Km}$ dengan jarak traking sejauh $10 \mathrm{Km}$ mulai dari Pos Way Kanan menuju SRS (Suaka Rhino Sumatera). Dari 4 stasiun yang dibuat, semua stasiun memiliki karakteristik berbedabeda jenis anggrek yang ditemukan, namun untuk satu jenis anggrek yakni anggrek kelapa hampir pada setiap stasiun ditemukan, hal ini dikarenakan jenis anggrek kelapa (Coelogyne foerstermanni) merupakan jenis anggrek tanah yang banyak ditemukan di Hutan Resort Way Kanan, karena karakteristik anggrek kelapa yang menyukai daerah tropis dengan kelembaban yang cukup, sesuai dengan kondisi di Hutan Resort Way Kanan yang merupakan salah satu hutan tropis di Indonesia. Anggrek kelapa di Hutan Resort Way Kanan ditemukan pada tempat atau habitat yang banyak seresah dan kondisi tanah yang lembab, hal inilah yang menjadi alasan mengapa anggrek kelapa banyak ditemukan di Hutan Resort Way Kanan. Menurut Hasanudin (2009) anggrek jenis ini menyukai tempattempat yang teduh dan lembab. Apabila anggrek kelapa merupakan salah satu jenis anggrek yang banyak ditemukan, maka anggrek Cymbidium golden merupakan salah satu jenis anggrek yang paling sedikit ditemui pada semua stasiun, hal ini dikarenakan saat ditemukan anggrek ini tumbuh tidak jauh dari alang-alang, alang-alang merupakan salah satu contoh tanaman yang mengandung alelokimia. Menurut Mulyoutami (2010), akar dan rimpang alang-alang melepaskan senyawa organik yang menghambat proses perkecambahan dan pertumbuhan awal berbagai jenis tanaman atau dikenal dengan istilah alelopati, hal ini dapat menjadi pengaruh penghambat pertumbuhan anggrek Cymbidium golden. Kedua jenis anggrek ini ditemukan dari stasiun-stasiun yang telah dibuat. 
Stasiun 4 merupakan stasiun yang ditemukan anggrek paling banyak jika dibandingkan dengan stasiun yang lain, satsiun 4 memiliki kondisi dengan kelembaban $85 \%$, suhu mencapai $28^{\circ} \mathrm{C}$ dengan intensitas cahaya $0,6 \%$ dan $\mathrm{pH}$ sebesar 9,1. Apabila dilihat dari kondisi pada stasiun 4 yang memiliki intensitas cahaya $0,6 \%$ merupakan salah satu faktor tumbuh dari anggrek. Menurut Indarto (2011), tanaman anggrek secara umum dikenal sebagai tanaman yang tidak menyukai paparan sinar matahari langsung, walaupun sebagian kecil jenis anggrek tumbuh di bawah sinar matahari langsung. Sedangkan menurut Assagaf (2012), anggrek pun memerlukan sinar matahari untuk tumbuh dan berbunga, rata-rata anggrek memerlukan sinar sekitar 30$60 \%$, disamping sebagian kecil memerlukan atau menyukai hampir $100 \%$.

Suhu pada stasiun 4 adalah $28^{\circ} \mathrm{C}$ yang merupakan suhu yang sesuai dengan syarat tumbuh anggrek, menurut Indarto (2011) suhu yang paling dingin untuk pertumbuhan anggrek adalah $12,7^{\circ} \mathrm{C}$, dan untuk suhu normal anggrek adalah kisaran $15^{\circ} \mathrm{C}$ $28^{\circ} \mathrm{C}$. Jika dilihat dari pernyataan tersebut maka suhu pada stasiun 4 adalah suhu normal untuk tumbuh anggrek.

Kelembaban pada stasiun 4 adalah $85 \%$, kelembaban ini berkaitan dengan banyaknya partikel air di udara, menurut Indarto (2011) anggrek akan tumbuh optimal pada kelembaban udara $65-90 \%$. Dari pernyataan tersebut kondisi kelembaban pada stasiun 4 lebih tinggi dari syarat tumbuh anggrek yang berkisar antara $65-90 \%$, akan tetapi anggrek dapat beradaptasi dengan baik walaupun dengan kelembaban demikian.

Apabila dilihat dari kondisi lingkungan anggrek yang ditemukan pada stasiun 4 di Hutan Resort Way Kanan memiliki kondisi normal untuk tumbuh anggrek, sehingga tidak sedikit anggrek yang ditemukan pada hutan tropis ini. Way Kambas beriklim tipe $b$ yang memiliki suhu $28,5^{\circ} \mathrm{C}$ dengan curah hujan berkisar anatar 2500$3000 \mathrm{~mm} / \mathrm{th}$. Hutan Resort Way Kanan memiliki keanekaragaman flora yang tinggi, sehingga memungkinkan untuk dijumpai anggrek pada hutan tropis ini.

23 spesies yang ditemukan di Hutan Resort Way Kanan dilakukan identifikasi, ternyata ada 14 spesies dan 9 genus anggrek yang ditemukan, 9 genus yang ditemukan belum bisa diidentifikasi atau diputuskan termasuk jenis atau spesies apa, karena anggrek yang ditemukan di Hutan Resort Way Kambas rata-rata belum berbunga, sedangkan yang membedakan jenis anggrek satu dengan anggrek lain, salah satunya adalah bunga. Setelah 23 jenis anggrek teridentifikasi maka dilakukan analisis untuk mengetahui indek keanekaragaman, dan diperoleh nilai 1,3. Nilai 1,3 jika menurut Shannon-Wiener dalam Fachrul (2007), menunjukan bahwa keanekaragaman spesies pada Hutan Resort Way Kanan adalah melimpah sedang, hal ini juga diperkuat dengan hasil analisis kerapatan relatif dan kerapatan spesies yang bernilai masing-masing $88,36 \%$ dan $46 \%$. Melimpah sedang maksudnya adalah kemelimpahan anggrek di Hutan Resort Way Kanan sedang yakni tidak begitu banyak yang ditemukan.

Jenis anggrek yang ditemukan di Hutan Resort Way Kanan ada tipe epifit dan teresterial. Epifit adalah jenis anggrek yang tumbuhnya menempel atau menumpang di pohon lain, namun tidak merugikan tanaman yang ditumpanginya. Menurut Indarto (2011), anggrek epifit pada habitat aslinya biasanya menempel pada pohon 
besar (meskipun tidak menutup kemungkinan pada pohon kecil) karena pohon besar cenderung memiliki kulit kasar yang memungkinkan anggrek untuk merekatkan akarnya. Oleh karena itu tidak aneh jika anggrek banyak ditemukan di Hutan Resort Way Kanan, karena keanekaragaman flora di Hutan Resort Way Kanan tinggi dan banyak ditemukan pohonpohon besar yang merupakan tempat menumpang anggrek epifit. Selain anggrek epifit di Hutan Resort Way Kanan juga ditemukan anggrek jenis teresterial yang merupakan jenis anggrek geofit yang akan tumbuh langsung di tanah dan sebagian diantaranya membutuhkan sinar matahari langsung.

Hasil dari penelitian yang telah dilakukan didapatkan data sebanyak 23 jenis anggrek dengan 9 genus dan 14 spesies. Identifikasi anggrek yang sudah diketahui genus dan spesiesnya, hal ini dilihat pada ciri-ciri umum yang dimiliki genus atau spesies tersebut dengan membandingkan sumber yang ada dan hasilnya mendekati sama, namun ada beberapa anggrek yang belum diketahui spesies atau jenisnya, hal ini dikarenakan anggrek tersebut hanya dapat dilihat secara umum yakni pada bagian daun saja yang tidak memiliki spesifikasi, sehingga sulit untuk mengidentifikasi jenis atau spesiesnya.

Kegiatan inventarisasi anggrek (Orchidaceae) di Hutan Resort Way Kanan ini menghasilkan beberapa anggrek alam atau anggrek spesies yang cukup beragam. Hasil dari pendataan ini dapat dijadikan sebagai salah satu sumber informasi bagi siapa saja yang membacanya. Ada beberapa jenis anggrek yang ditemukan di Hutan Resort Way Kanan yang memiliki nilai keanekaragamn cukup besar, selain itu dari beberapa jenis anggrek yang ditemukan ada beberapa yang diantaranya memiliki status dilindungi menurut Peraturan Pemerintah Nomor 7 Tahun 1999, sehingga hasil dari penelitian ini dapat dijadikan sumber informasi dalam melestarikan plasma nutfah dan menambah pengetahuan secara umum mengenai anggrek yang dapat dibaca dan dipelajari oleh semua kalangan termasuk siswa-siswi Sekolah Menengah Kejuruan dalam bentuk buku-buku ringkasan anggrek di Hutan Resort Way Kanan. Pengembangan hasil penelitian berupa sumber infomasi dalam bentuk buku ringkasan beralasan karena, buku merupakan salah satu sumber belajar untuk memperoleh informasi. Buku memiliki beberapa keunggulan misalnya, tahan lama, mudah di bawa kemana-mana, bisa dibaca kapan saja, dapat memuat informasi lebih banyak da nisi pembelajaran dapat diperbanyak dengan cepat, seperti menurut Karwono (2012), dengan lahirnya sumber belajar cetak, maka isi pembelajaran dapat diperbanyak dengan cepat dan disebarkan ke berbagai pihak dengan mudah, sehingga merupakan kejutan baru dalam sistem instruksional pada saat itu. Selain buku ringkasan sebagai sumber informasi pelestarian plasma nutfah, hasil penelitian ini juga nantinya akan disusun baner informasi, agar semua kalangan dapat membacanya.

Berdasarkan hasil analisis angket dari para ahli oleh dosen dan pihak Resort Way Kanan Balai Taman Nasional Way Kambas mengenai sumber informasi berupa buku ringkasan yang dibuat menghasilkan rata-rata persentase sebesar $75,71 \%$. Hasil 75,71\% tergolong dalam kriteria layak, hal ini sesuai dengan pendapat Riduwan dalam Puspitadewi (2014). Sedangkan menurut Kristiningrum 
(2007) hasil $75,71 \%$ tergolong baik, dengan demikian dapat disimpulkan bahwa sumber informasi berupa buku ringkasan yang dikembangkan dari segi informasi dan tampilan layak untuk dijadikan sumber informasi pelestarian plasma nutfah berupa buku ringkasan.

\section{KESIMPULAN DAN SARAN Kesimpulan}

Berdasarkan inventarisasi Anggrek (Orchidaceae) yang dilakukan di Hutan Resort Way Kanan dapat disimpulkan bahwa:

Jenis anggrek yang ditemukan di Hutan Resort Way Kanan memiliki keanekaragaman dengan kriteria sedang dengan ditemukannya 23 jenis anggrek dalam perjalanan kurang lebih $10 \mathrm{Km}$ menyusuri hutan Pos Way Kanan hingga SRS (Suaka Rhino Sumatera), dengan terdiri dari 9 genus dan 14 spesies.

Anggrek yang ditemukan pada setiap stasiun memiliki habitat yang beragam, ada yang menyukai kondisi habitat yang cukup panas, lembab dan basah. Kriteria habitat pada 4 stasiun yang telah dibuat adalah pada stasiun 1 sedikit kering, kriteria anggrek yang ditemukan berukuran tidak terlalu besar dan memiliki daun yang tebal, stasiun 2 sedikit lembab, memiliki kriteria anggrek yang berukuran besar dan cenderung tidak begitu menyukai matahari, stasiun 3 agak lembab, anggrek yang ditemukan kebanyakan menyukai tempat yang teduh, dan pada stasiun 4 lembab. Karakteristik anggrek yang ada di Hutan Resort Way Kanan secara umum merupakan jenis anggrek yang hidup pada hutan tropis, yakni jenis anggrek yang menyukai suhu sedang dan kelembaban cukup. Jenis anggrek yang paling banyak ditemukan di Hutan Resort Way Kanan adalah jenis anggrek kelapa, dengan karakteristik daun yang menyerupai daun kelapa saat tunas, dan memiliki umbi pada bagian akarnya. Sedangkan jenis anggrek yang paling sedikit ditemukan adalah Cymbidium golden, dengan karakteristik termasuk jenis anggrek teresterial dan berdaun tipe lanset.

Hasil penenelitian ini dijadikan sumber informasi berupa buku ringkasan dan baner informasi mengenai Anggrek di Hutan Resort Way Kanan yang dapat memberikan informasi dalam pelestarian plasma nutfah.

\section{Saran}

Penelitian sejenis ini dapat dilakukan untuk penelitian selanjutnya dengan menggunakan objek yang berbeda. Hasil penelitian ini dapat dijadikan sumber informasi dalam melestarikan plasma nutfah. Selain itu hasil penelitian ini juga dapat digunakan sebagai seorang pendidik dalam mata pelajaran pertanian pada Sekolah Menengah Kejuruan.

\section{DAFTAR RUJUKAN}

Fachrul, Ferianita Melati. 2007. Metode Sampling Bioekologi. Jakarta: Bumi Aksara.

Hasanuddin. 2009. Jenis Tumbuhan Epifit di Kawasan Cagar Alam Jantho Kabupaten Aceh Besar (Variety of epiphyti Orchids in Jantho Nature Reservation Aceh Besar Distric). Disertasi tidak diterbitkan. Banda Aceh: Program Studi Pendidikan Biologi FKIP Unsiyah.

Indrawan, Mochamad. 2007. Biologi Konservasii. Jakarta: Yayasan Obor Indonesia.

Indarto, Novo. 2011. Pesona Anggrek Petunjuk Praktis Budi Daya dan Bisnis Anggrek. Yogyakarta: Cahaya Atma Pustaka. 
Kartohadiprodjo, Nies Sumarti. 2009. Asiknya Memelihara Anggrek. Jakarta: Gramedia Pustaka Utama.

Karwono, \& Mularsih Heni. 2012. Belajar dan Pembelajaran Serta Pemanfaatan Sumber Belajar. Ciputat: Cerdas Jaya.

Kristiningrum. 2007. Pengembangan Multimedia Pembelajaran Interaktif dengan Macromedia Authoware 7.0 pada Materi Fisika Sekolah Menengah Atas (SMA) Pokok Bahasan Kinematika Gerak Lurus. Disertasi tidak diterbitkan. Semarang: Program Sarjana Pendidikan Fisika Universitas Negeri Semarang.

Kuswanda, Wanda. Satyawan Pudyatmoko. 2011. Seleksi Tipe Habitat Orangutan Sumatera (Pongo abelii Lesson) di Cagar Alam Sipirok, Sumatera Utara: Jurnal Penelitian Hutan dan Konservasi Alam. (Online). Vol.9.No.1.

(http://scholar.google.co.id).

Mulyoutami, Elok. Dkk. 2010. Perubahan Pola Perladangan: Pergeseran Persepsi Mengenai Para Peladang Indonesia. Bogor: Wold Agrosforestry Centre.

Puspitadewi, Septiana. 2014. Profil LKS Materi Perubahan Lingkungan Berorientasi Kurikulum 2013 untuk Melatih Berfikir Siswa: Bioedu ISSN: 2302-9528. Vol. 3. No. 2. Mei 2014.

Sanjaya, Wina. 2011. Strategi Pembelajaran Berorientasi Standar Profesi Pendidikan. Jakarta: Prenada Media Group. 